\title{
Translating for linguistic minorities in Northern Ireland: \\ A look at translation policy in the judiciary, healthcare, and local government
}

\author{
Gabriel González Núñez \\ KU Leuven
}

\begin{abstract}
Europe is a multilingual continent where at least three types of languages co-exist: dominant languages, autochthonous minority languages, and new minority languages. From a policy standpoint, planning for speakers of these languages and their needs becomes a complex matter in which many actors with different interests are involved. Of the many questions which policy makers must deal with, the role of translation is often unexplored. However, in any multilingual territory, the adoption of a language policy implies decisions to translate or not. With that understanding, this paper explores the role of translation in language policy in Northern Ireland. By so doing, the paper highlights the translation implications of policy decisions. This helps illustrate the complexity of language and translation policy. This paper explores the complexities of language policy as seen in translation policies for speakers of Irish, Ulster Scots and new minority languages. Specifically, it considers translation policies in the judicial system, in the healthcare system, and in local governments.
\end{abstract}

Keywords. language policy, translation policy, Northern Ireland, courts, healthcare, local government

\section{Introduction: From language policy to translation policy}

In the past decades, issues raised by multilingualism in Europe have come to the forefront in academic, legal, and policy circles. There is now a recognition of Europe as a multilingual continent, where at least three types of languages co-exist: institutional, dominant languages (often termed 'official languages'), autochthonous minority languages (often termed 'minority languages'), and new minority languages (often termed 'immigrant languages'). Such a medley of languages poses challenges for policy makers.

Issues pertaining to language are often considered under the term 'language policy'. The term itself is hard to define — no single definition carries universal approval (O'Rourke \& Castillo, 2009, p. 34) — and it competes with other terms such as language planning, language management, language engineering and even language governance (Walsh, 2012, p. 324). Even so, one definition that has become very influential is the one proposed by Spolsky, who argues that language policy is a concept that encompasses language practices, language beliefs, and language management. Language practices are 'the actual language practices of 
the members of a speech community' (Spolsky, 2012, p. 5); language beliefs are 'the values assigned by members of a speech community to each variety and variant and their beliefs about the importance of these values' (Spolsky, 2012, p. 5); and language management refers to 'efforts by some members of a speech community who have or believe they have authority over other members to modify their language practice' (Spolsky, 2012, p. 5). This last element of his definition is what some prefer to call language planning (Spolsky, 2012, p. 5).

Bearing this in mind, we should remember that the complexity of today's multilingual democracies means that language policy of necessity must include choices about the use or non-use of translation. Thus, translation, as a part of language policy, plays a role in each of Spolsky's three general areas. In this sense, we could talk about translation practices, translation beliefs, and translation management. Translation practices involve questions such as what texts get translated, into and out of what languages, where it takes place, who is tasked with it, what mode of interpreting is used, etc. Translation beliefs involve issues such as what the value is or is not of offering translation in certain contexts for certain groups or to achieve certain ends. Translation management refers to the decisions regarding translation practices made by people in authority. This suggests that translation policies arise as a consequence of language policies. There is, in the words of Meylaerts, '[n]o language policy without translation policy' (2011b, p. 744).

And yet the term 'translation policy' is somewhat problematic for scholars in the field of translation studies. The idea of translation policy has meant so many things to so many authors that it cannot be satisfactorily defined. Meylaerts (2011a, pp. 163166) indicates that policy has been understood by translation scholars to mean the strategies employed by translators while translating; scholarly advice on the role of translation and translators in society; the factors that govern the type, timing, and extent of texts to be translated; the conduct of the government or administrative authorities vis-à-vis translation; the legal rules that govern translation in the public sphere; and the behavior of non-official institutions to promote (or not) translation in specific settings. Thus, in translation studies the term policy has become a sort of 'umbrella term' that risks 'becoming an empty notion with little conceptual surplus value' (Meylaerts, 2011a, p. 163). Consequently, if we are to move forward with a study of translation policy, we need to offer a less uncertain understanding of the term.

Meylaerts herself has attempted to do this. She has proposed a definition of 
translation policy as 'a set of legal rules that regulate language use for purposes of education and communication, the latter covering the language of legal affairs, of political institutions, of the media, and of administration' (2011b, p. 744). This definition, while helpful, may be too narrow for current purposes. If we recognize that translation policy does not exist independently of language policy and then lean on Spolsky's understanding of language policy as language practices, beliefs, and management, it becomes apparent that translation policy can be helpfully understood as more than a set of legal rules that bear on the use of translation. Meylaerts' definition can be conceptually linked to language management, and then referred to as translation management. Yet as indicated above, translation policy can also be understood to bear in matters of practice and belief. Consequently, in this study we will take Meylaerts' definition of translation policy as a starting point and add upon it. We will understand translation policy to be translation management, practice, and beliefs in any given setting. 1

With that understanding, this paper explores translation policy in Northern Ireland. Specifically, it looks at Northern Ireland as a case study of the way in which providing (or withholding) translation is part and parcel of language policy. In Northern Ireland, the translation implications of policy decisions help illustrate the complexity of putting language policy into practice. This paper will attempt to describe translation management, practices and beliefs and will shed light on some of the different actors and objectives which interact in the provision of translation. By doing this, it will reveal one aspect of language policy, namely translation, to be a complex matter that involves fluid interactions between many different actors with varying objectives.

Northern Ireland is well-suited for illustrating this for several reasons. One such reason is that it is a region where there is a strong dominant language that has been institutionalized (English), two autochthonous minority languages (Irish, Ulster Scots), and over seventy new minority languages. This paper will explore the complexities of language policy as seen in translation policies for speakers of Irish, Ulster Scots and new minority languages. (The term translation will be understood to encompass both written translation and oral interpreting.)

Because of Northern Ireland's complex recent history, there are many factors that affect language policy. Methodologically, this article takes a top-down approach to exploring the role of translation as part of that language policy. It first considers the constitutional enactments that weigh on language policy, and consequently translation policy, and then other legislative enactments that affect how actors approach language and consequently translation. 
Then, it will consider the policy documents adopted by specific actors as a result of those constitutional and legislative enactments. These legislative enactments and policy documents, which can be conceptualized as explicit policy, amount to evidence of translation management. The article will also consider translation practices by referring to reported practice of the institutions that provide translation in specific settings, namely in the judicial system, in the health and social care systems, and in local governments. Such reported practice can be conceptualized as implicit policy. The data was gathered through reports available online and through questions put forth through Freedom of Information Act requests by the researcher. Finally, a discussion of translation beliefs will be included as part of the paper's analysis. (The paper will not consider the role of literary translation but will instead focus on public spaces where government interacts with the inhabitants of a territory.)

\section{Northern Ireland's Linguistic Background}

Northern Ireland's linguistic landscape will first be discussed, an understanding of which is important in terms of policy since policies often adopt a reductive view of language practices on the ground. First, we point out that even though English did not originate in the island of Ireland, it is the language spoken by the overwhelming majority of people in Northern Ireland. According to the 2011 census, almost $97 \%$ of the population over the age of 3 have English as their "main language" (Northern Ireland Statistics and Research Agency, 2012, p. 17). English's dominant position is clearly attested by the place of English as the main language of government institutions. But there are other autochthonous languages in the region, namely Irish and Ulster Scots.

Regarding Irish (Gaelic), 10,65\% of the population over 3 report some ability in Irish, while 3,74\% claim they can speak, read, write and understand it (Northern Ireland Statistics and Research Agency, 2012, 18). A lesser percentage, 0,24\% of the population, claim that Irish is their main language (Northern Ireland Statistics and Research Agency, 2012, p. 17). This may be related in part to the fact that only 'a very small percentage of Irish-speakers in Northern Ireland are native speakers' (Dunbar, 2004, p. 102). Even so, a 'substantial section of the population' seem to see it as an important part of their identity (Dickson, 2003, p. 19).

Regarding Ulster Scots (or Ullans), there is some controversy as to whether it 
is an independent language at all or a form of Scots or of English (see, e.g., Gilbert, 2003, p. 78; Laird, 2001, p. 37; Smyth \& Montgomery, 2005, p. 60), but for purposes of this article, it will be treated as an independent language. According to the 2011 census, $8,08 \%$ of the population over 3 report some ability in Ulster Scots, while 0,94\% claim they can speak, read, write and understand it (Northern Ireland Statistics and Research Agency, 2012, 18). Perhaps because of its proximity to English, it is hard to find data on 'how many people use [it] as the sole or primary medium of communication' (Dunbar, 2007, p. 107).

There is some tension regarding the treatment of these two autochthonous minority languages. These languages are symbols of cultural identity. They represent cultural identities that historically were seen as being fundamentally at odds with each other. This can be traced back to the Plantation of Ulster, when the British Crown set about attracting English, Scottish, and Welsh colonists into the North of Ireland. Most of the newcomers spoke a language other than Irish, and were Protestant instead of Catholic (Darby, 1995, 16). Thus, the North of Ireland became inhabited "by two hostile groups" that "identified their differences as religious and cultural" (Darby, 1995, 16). In this context, languages became important cultural symbols in Northern Ireland's conflicts. Their symbolic importance as cultural identifiers led to issues regarding Irish and Ulster Scots being included in the peace negotiations (see section on the region's constitutional structure below). And they continue to be symbols of identity now that Northern Ireland has become a post-conflict society. As McDermott points out,

Cultural expressions of 'Irishness' are often viewed as tangible support for Irish nationalist politics, particularly the political unification of the island; whereas, an articulation of British identity is widely regarded as supporting the traditional unionist stance of protecting the Northern Ireland's position [sic] within the UK. (2012, pp. $187-188)$

Thus, the political divide between nationalists and unionists has played along language lines. 2 For example, the perception has arisen that unionists have championed Ulster Scots in opposition to nationalist support for Irish (Dunbar, 2003, p. 40; see also McEvoy, 2011, p. $60)$.

Not surprisingly, then, language policy following the Troubles has focused mostly on Irish and Ulster Scots (McDermott, 2012, p. 188). This is reflected in the wording of the Good Friday Agreement regarding languages:

All participants recognise the importance of respect, understanding and tolerance in relation to linguistic diversity, including in Northern Ireland, the Irish language, 
Ulster-Scots and the languages of the various ethnic communities, all of which are part of the cultural wealth of the island of Ireland.

As can be seen in the above clause, the Good Friday Agreement acknowledges that new minority languages are also present in Northern Ireland. These languages were brought into the region by subsequent waves of immigration that date back to the 1930s. According to Holder (2003, p. 27), at least 70 new minority languages are spoken by members of minority ethnic communities in Northern Ireland. Since then, immigration has increased as a result of the 2004 and 2007 enlargements of the EU (McDermott, 2011, pp. 99-107). Currently, immigrants from places like China, the Indian sub-continent, Lithuania, Poland, and Portugal can be found in Northern Ireland. According to the 2011 census, Polish is, after English, the most spoken language in Northern Ireland, with 1,02\% of the population over 3 claiming it as its main language (Northern Ireland Statistics and Research Agency, 2012, p. 17). Other languages in Northern Ireland include Chinese, Hungarian, Malayalam, Latvian, Lithuanian, Portuguese, Russian, Slovak, and Tagalog (Northern Ireland Statistics and Research Agency, 2012, p. 17).

\section{Translation policy as a result of Northern Ireland's constitutional and non- discrimination framework}

In Northern Ireland, translation is produced in part as a result of the constitutional structure of the region and its non-discrimination legislation. Both the constitutional structure and non-discrimination legislation emerged in the course of the peace process (McDermott, 2012, 189). As such, both are part of an effort by policy makers to bring about stability through the sharing of power and the promotion of equality. Neither the constitutional structure nor anti-discrimination legislation foresee an explicit role for translation, but in reality translation becomes a tool for achieving the broader policy aims of creating a stable, equitable society.

One of the key documents that contributes to the constitutional structure of Northern Ireland is the Good Friday Agreement. As stated in the previous section, the Agreement makes provision for respecting linguistic diversity. This is not surprising given that in Northern Ireland, Irish and Ulster Scots have become powerful political symbols (Nic Craith, 2001, pp. 4-9). The Agreement and the agencies that were created as a result were meant 'to incorporate culture, identity and minority language concerns within the wider framework of conflict resolution, facets of life in the region which had previously been absent from official 
policy' (McDermott, 2012, p. 188). In terms of language, the Agreement ushered in a new era (Kirk \& Ó Baoill, 2001, p. 16). It did so by setting out linguistic promotion as a policy objective for the devolved government (Rooney, 2001, p. 55). As regards obligations toward linguistic minorities, however, the agreement is quite vague (Rooney, 2001, pp. 58-59).

The Good Friday Agreement was an important development in the creation of a devolved government in Northern Ireland. The Agreement is given the force of law mainly through the Northern Ireland Act 1998, as amended by the Northern Ireland Act (St Andrews Agreement) 2006. Parts of the Act required further legislation for implementation, such as the North/South Co-operation (Implementation Bodies) (Northern Ireland) Order 1999. This Order created the North/South Language Body (Schedule 1, Article 1(e)), which is charged with 'the promotion of the Irish language' and with the 'promotion of greater awareness and use of Ullans' (Schedule 1, Annex 1, Part 5). Such promotion is carried out by two agencies: Foras na Gaeilge and Tha Boord o Ulstèr-Scotch, respectively (Dunbar, 2003, p. 38). While neither of these two agencies is explicitly charged with translating, both have engaged translation as a way to fulfill their policy aims of promoting Irish or Ulster Scots. For example, Foras na Gaeilge has an accreditation system for translators working with Irish (Northern Ireland Assembly, 2008). This and other efforts in the translation sector, such as creating a memory-assisted translation tool, are considered by Foras na Gaeilge to be 'key achievements' in promoting the Irish language (Houses of the Oireachtas, 2010). Tha Boord o Ulstèr-Scotch, in turn, handles translation work for Ulster Scots (Rooney, 2001, p. 57). Regarding new minority languages, while the Good Friday Agreement does call for tolerance and understanding of 'the languages of the various ethnic communities,' there is no equivalent agency charged with responsibilities vis-à-vis such languages (Kymlicka, 2007, pp. 506-507).

As stated above, the Northern Ireland Act was an important vehicle for the implementation of the Good Friday Agreement. The Act helped bring about devolution in Northern Ireland. It created the Northern Ireland Assembly and, among other things, specifies human rights and equal opportunity. In this regard, the Act places a duty on public authorities to 'have due regard to the need to promote equality of opportunity' between specific groups, including people of different racial groups (Section 75(1)(a)). The link between race and language is not explicit, but legally speaking, ethnicity is linked to race, and language is an element of ethnicity (Dunbar, 2001, p. 238). Even so, at first glance this Act seems to say nothing regarding languages or, by extension, translation. However, in trying to fulfill this statutory duty to promote equality of opportunities, public bodies find themselves engaging in translation. If someone who lacks the needed English proficiency approaches a public body, it 
is that public body's responsibility to bridge the language gap so as to make sure the non- or limited-English speaker has the same opportunities as those who do speak English. This translation approach can arguably help build good relations by helping bridge language barriers. Under the Act, public authorities in Northern Ireland are to carry out their functions having 'regard to the desirability of promoting good relations between persons of different religious belief, political opinion or racial group' (Section 75(2)).

This brings us to anti-discrimination legislation, which is the other way in which policy makers have put translation on the agenda in Northern Ireland. Anti-discrimination legislation in Northern Ireland comes from a patchwork of laws. As regards translation, the Race Relations (Northern Ireland) Order 1997 is worth considering. The Act bans direct and indirect discrimination in specific areas, including the provision of services 'to the public or a section of the public' (section 21). Because under the Act there can be no racial discrimination in accessing services among racial groups, including those of different ethnic or national origin, the Act can be understood to have created a duty to not discriminate between users of different languages (Dickson, 2003, p. 21). If a user of a specific language cannot access a service because he or she is unable to use English, this would be discrimination in favor of English speakers. In order to avoid this, providers of public services at times turn to translation as a practical solution to achieve a broader statutory aim.

In essence, the statutory framework in Northern Ireland indicates that languages should be respected and valued in a climate that fosters equality of opportunity, good relations, and does not discriminate based on racial grounds. Carrying this policy forward is a complex matter. A number of policy decisions and documents have been issued to that end. It is in this context that certain policy documents that impact translation have been produced.

For example, a policy document titled $A$ Shared Future was issued 3 that recognizes language diversity to include English, autochthonous minority languages, sign languages, and new minority languages as 'an intrinsic part of our cultural capital' (Community Relations Unit, 2005, p. 35). The policy supports specific steps in favor of each of the language clusters, including the work of a 'thematic group on language' working under the Northern Ireland Racial Equality Forum (Community Relations Unit, 2005, p. 36). The Racial Equality Forum has issued guidelines on the use of translation and interpreting in the public and private sectors. While these guidelines are not binding, they are designed to help service providers make decisions about how to bridge the language barrier in a way that is true to the statutory duties described above. These guidelines refer to written translation and interpreting for those 
who do not have a sufficient command of English.

The Best Practice Guidelines on the Use of Translation document emphasizes 'the need to adopt a selective approach' when it comes to written translation (Racial Equality Forum, 2009, p. 3). The Guidelines stress that an explicit obligation to translate is found only in criminal proceedings. It is therefore recommended that translation be 'reduced' except inasmuch as it 'builds integration and cohesion' (Racial Equality Forum, 2009, p. 4). The Guidelines indicate that translation is merited in some situations, including where it enables 'specific individuals to access essential services' (Racial Equality Forum, 2009, p. 4). Thus, public service providers should not engage in automatic translation, adopting instead a selective approach that helps bring about increased participation and cohesion.

A similar document deals with interpreting. The Best Practice Guidelines on the Use of Interpreters document points out that '[c]ompetent interpreting makes a major contribution to effective and efficient conversations/discussions and good service provision' (Racial Equality Forum, 2008, p. 3). Thus, instead of telling service providers to really consider whether they need to interpret, the document aims at helping them 'in the development of good practice when using interpreters' (Racial Equality Forum, 2008, p. 3).

In analyzing the legislative framework in Northern Ireland for its effect on how translation is used to deal with linguistic minorities, note should be made of the European Charter for Regional or Minority Languages (ECRML). The ECRML is a Council of Europe treaty that calls for measures of support for minority languages in Europe. It has been ratified by the UK, but not incorporated into domestic law. Rather, Westminster has charged the devolved government of Northern Ireland with the implementation of the ECRML for Irish and Ulster Scots in its respective jurisdiction. Thus, while there is no legislation mandating the use of Irish or Ulster Scots, government agencies in Northern Ireland seek to comply with the ECRML in the conduct of official business.

The ECRML has been ratified by the UK in Part II for Ulster Scots and Parts II and III for Irish. In order to help each government organization fulfill these Part II and Part III obligations, an Interdepartmental Charter Implementation Group (ICIG) was set up in 2001 to 'oversee and monitor the implementation of the Charter by Government Departments in Northern Ireland' (Northern Ireland Assembly, 2009). The ICIG has issued a Guidance on Meeting UK Government Commitments in Respect of Irish and Ulster Scots. In this document, all departments in Northern Ireland are instructed to 'develop and circulate to their staff their own tailored Code of Courtesy' for handling everyday situations when interacting with members of the public who wish to transact their business in Irish or Ulster Scots 
(Interdepartmental Charter Implementation Group, 2005, p. 9). While these Codes of Courtesy are not statutorily mandated, institutions that do employ Codes of Courtesy may have to engage in some form of translation.

This overview of the language and translation implications of the constitutional structure of Northern Ireland as well as its anti-discrimination framework already point to a complex system of translation where different policy documents and different actors come into play. To complicate matters, there are specific considerations that affect sectors like the judiciary, the healthcare system, and local governments. These will now be explored.

\section{Translation policy in Northern Ireland's judiciary}

In considering translation in Northern Ireland's judiciary, we will see that language requirements interplay with human rights concerns. The courts in Northern Ireland, like most courts in the UK, have a legal monolingual culture (Dunbar, 2004, p. 96). (The major exception is courts in Wales.) This monolingual culture in Northern Ireland is secured, to a great extent, by the Administration of Justice (Language) Act (Ireland) 1737. This act of Parliament was part of a process across Great Britain and Ireland to have the courts become monolingual in English (Dunbar, 2007, pp. 96-97; Holder, 2010, p. 15). The Act mandates that '[a]ll proceedings in courts of justice, patents, charters, pardons, commissions, etc. shall be in English' (section I) except for 'names of writs, process or technical words' (section II). This effectively bars the use of autochthonous minority languages in the courts of Northern Ireland. Such an effect is ironic, as the languages that were actually targeted by the Act in 1737 were French and Latin (Larkin, 2010, p. 9). For speakers of Irish and Ulster Scots, the effect of the Act has been negative because they cannot use their preferred language in court (unless that language is English). Ó Flannagáin (2010, p. 11) states: 'Many Irish speakers [...] are reluctant, embarrassed or even frightened to use Irish with the State, and this is particularly true in relation to the law.'

The validity of the Act was challenged in Mac Giolla Cathain. In this case, the applicant wished to apply to court for a liquor license to sell at a concert. He was advised by the Northern Ireland Court Service4 that the application had to be submitted in English. In the ensuing lawsuit, the Act was upheld. The Court of Appeal in Northern Ireland observes that 'English is the working language of the court and this will remain so unless and until the 
matter is changed by statute'

In light of this, all court proceedings and business transacted in court must be in English. However, in keeping with the ECRML, the Northern Ireland Courts and Tribunals Service (the courts' administrative agency) has adopted Codes of Courtesy for Irish and Ulster Scots. Consequently, business transacted out of court, such as at the Fixed Penalty Office and the Court Funds Office, is to be transacted according to the Codes of Courtesy. These Codes of Courtesy rely on translation for their proper functioning.

\section{Criminal courts in Northern Ireland}

Absent a statute that grants the right to use Irish, Ulster Scots or any other language in Northern Ireland, those who can speak English must use English in their interactions with court. Under the Human Rights Act 1998 (HRA), however, those who cannot communicate in English properly are permitted to use some other language. The HRA incorporates the European Charter on Human Rights (ECHR) into UK law, including Articles 5 and 6 of said charter. Article 5(2) indicates that upon arrest, the person arrested must be informed of the charges in a language that he or she understands. When there is a language barrier, this can only be achieved through translation. Article 6 guarantees the right to 'the free assistance of an interpreter' in trail settings. Because of the HRA, mechanisms have been instituted for translation whenever those involved with the justice system in criminal matters are unable to speak English. For example, the Police Service of Northern Ireland has face-to-face and telephone interpreters that are available around the clock in case of hate crimes that involve non-English speakers (Department for Communities and Local Government, 2010, p. 57).

\section{Civil and Family Courts in Northern Ireland}

When a party that does not speak English comes before a non-criminal court, the expectation is that such party will pay for their own interpreters (Northern Ireland Courts and Tribunals Service, 2012a). However, if the case involves children, domestic abuse, or committal of an individual who does not speak English, the court will provide interpreters (Northern Ireland Courts and Tribunals Service, 2012a). Similarly, if an individual cannot speak English, is unable to afford an interpreter, and does not otherwise qualify for publicly funded interpreters, the judge will request a court interpreter (Northern Ireland Courts and Tribunals Service, 2012a). Regarding written translation in non-criminal proceedings, 
translation of documents will be provided by the courts if they are in a foreign language in cases involving things like parental child abduction (Northern Ireland Courts and Tribunals Service, 2012b, p. 8). In essence, with specific exceptions, the language policy for non-criminal courts is to proceed in English and allow parties to use their own interpreters, if needed.

In sum, the state will not provide translation for anyone who can speak English, and even for those who cannot, translation will only be provided in criminal proceedings or in narrow civil or family court proceedings. This means that English speakers, particularly fluent speakers of English, are better situated to access the court system than those who cannot use English.

\section{Translation policy in Northern Ireland's healthcare system}

Even though translation does not explicitly come up in legislative enactments related to healthcare, policies regarding human rights, non-discrimination, and language come to bear on translation in that setting. In part, this is the result of broader policies adopted through Westminster legislation, including the HRA. The HRA guarantees the right to life. If patients are unable to properly communicate with their healthcare providers, this could in some situations place the lives of patients at risk. Seen in this light, there will be situations when translation will be a tool for ensuring the right to life. Of course, not all interactions with the healthcare system are about keeping someone alive. Consequently, the HRA's role in shaping translation policy in healthcare is narrow but important.

In Northern Ireland, translation in healthcare situations where the right to life is not at stake is a way to comply with obligations under the Race Relations Order. The way this law creates a sense of duty to translate has been addressed in the above discussion regarding antidiscrimination on grounds of race. It is this type of understanding that leads to healthcare providers feeling they have a duty to provide translation in order to avoid discrimination.

When considering the HRA and the Race Relations Order, we could conclude that for healthcare in Northern Ireland, Westminster's human rights and nondiscrimination objectives in practice can only be accomplished through some translation efforts.

Because there is no explicit translation policy mandated for healthcare in Northern Ireland via legislation, this paper will look below legislation. Specifically, it 
will consider the healthcare direction given by the Department of Health, Social Services and Public Safety (DHSSPS), as provided locally by six Health and Social Care Trusts (HSC Trusts). Thus, we will consider not only the policy documents issued by the DHSSPS but also the translation policies of HSC Trusts.

The DHSSPS's view of translation can be found in the guide Racial Equality in Health and Social Care.5 Regarding language, the guide is informed by the understanding that 'Service users whose first language is not English can be at a major disadvantage in accessing health care' (Equality Commission for Northern Ireland, 2011, p. 6). To help overcome this 'major disadvantage,' the guide presents a list of best practices, including: (1) the use of trained interpreters; (2) the use of a hospital register of bilingual staff; (3) the use of language identification cards; and (4) the use of translated leaflets (Equality Commission for Northern Ireland, 2011, p. 6).

The DHSSPS's policy of using translation as a tool for promoting equality by removing major disadvantages can be seen in two efforts it has helped fund: the Northern Ireland Health and Social Services Interpreting Service (NIHSSIS) and the Accessible Formats Project. The former focuses on interpreting and the latter on written translation. We will briefly discuss each.

NIHSSIS was launched to help healthcare providers obtain access to interpreters when communicating with people with no or limited English skills (Department of Health, Social Services and Public Safety, 2008, pp. 23-24). NIHSSIS is intended to act as a regional interpreting provision service for all healthcare providers in Northern Ireland.6 It does not have its own interpreters but rather has a registry of face-to-face interpreters in the commercial sector (McDermott, 2011, p. 135). The NIHSSIS does not offer telephone interpreting or written translation (Department of Health, Social Services and Public Safety, 2008, p. 24).

To help healthcare providers with their needs for written translation, the Accessible Formats Project was launched (Department of Health, Social Services and Public Safety, 2008, p. 24). The project had two outcomes. First, it has translated an information booklet titled Health and Social Care in Northern Ireland into thirteen languages (Department of Health, Social Services and Public Safety, 2008, p. 24). Second, it has created a list of written translation providers in the form of a regional translations contract (Department of Health, Social Services and Public Safety, 2008, p. 24).

The five HSC Trusts that run hospitals7 rely on these initiatives by DHSSPS in their own translation efforts. The five Trusts are in step in considering translation as a way to help 
fulfill legislative duties regarding equality, good relations, and non-discrimination. The Trusts have adopted a number of measures for granting more equal access to speakers of new minority languages who have not obtained sufficient proficiency in English.

Regarding written translation, all five HSC Trusts indicate they will translate as needed upon request. Translation is outsourced to companies through the regional contract mentioned above. Additionally, two of the Trusts offer the option of translating their website via machine translation. Regarding interpreting, all five HSC Trusts offer telephone interpreting, usually for shorter, simpler matters or for emergencies. Face-to-face interpreting is generally reserved for longer, complex, or delicate matters. For this type of situations, the policy is not to use staff unless it's an emergency. (In two HSC Trusts, staff are instructed that they can handle short, routine matters, if they have the language skills.) Children, family, and friends are not recommended. All five trusts have NIHSSIS as their first option for face-to-face interpreting. When NIHSSIS is unable to provide interpreters, they also have contracted private-sector suppliers, as well as local community organizations such as the Chinese Welfare Association.

Translation efforts by HSC Trusts focus on individuals who lack enough knowledge of English to enjoy equal access to healthcare services. According to responses generated through FOI requests, four of the five trusts see Irish and Ulster Scots provision just as provision into any new minority language, which means it will be provided if the individual requesting it cannot effectively communicate in English. As this is highly unlikely, in practice, interpreting and translation is not provided into those two languages.

In essence, translation in healthcare settings is similar to that of judicial settings in that it is provided mainly for those who cannot speak English well enough. However, translation in the judiciary, especially in court, happens mostly as a result of the right to an interpreter incorporated through the HRA. Healthcare providers are concerned about the right to life and non-discrimination, concerns mostly absent in court proceedings.

\section{Translation policy in Northern Ireland's local government}

Generally speaking, there is no legislation explicitly mandating translation in local government in Northern Ireland, but under the constitutional and nondiscrimination legislation described above, translation to communicate with linguistic 
minorities takes place as a tool for other institutional objectives. In this regard, local governments in Northern Ireland are not unlike local governments in the rest of the UK.

For this section, data was obtained from 24 of the 26 local councils (see last paragraph of the introduction regarding method). A differential treatment is observed in the way local councils approach translation pertaining to new minority languages and autochthonous minority languages. And even in the latter category, there is a difference between the treatment of Irish and of Ulster Scots.

Regarding new minority languages, eight of 26 local councils report having policy documents to address issues pertaining to this type of language. Eleven local councils have made their websites translatable via machine translation. Regarding the provision of written translations, 20 councils report they do this. The type of documents translated include welcome packs, information leaflets, legal notices, and incoming correspondence. In some situations, the reply to incoming correspondence in a new minority language may be translated out of English into that language. No council handles this translation in house, and the organizations hired to do this work include private companies but also non-profit community organizations such as STEP (see McDermott, 2008, pp. 12-13). Local councils do not seem to collaborate with each other in the provision of written translation, even though the Belfast council offers links to organizations that have translated helpful materials. Regarding the provision of interpreting, 19 councils report they do this. Interpreting may be over the telephone or face to face, depending on the council and the circumstances. STEP is also a provider of interpreters, as are private companies. These translation services are driven by demand.

When approaching Irish and Ulster Scots, local councils usually take different paths. Of course, the areas where they may provide written translation or interpreting are the same, but the level of provision differs. Most local councils claim some sort of commitment to these two languages, often in vague terms that make it difficult to ascertain whether there is a policy to translate. Only two local councils state unequivocally that they will not provide any written translation or interpreting into either of these two languages.

Regarding written translation, 11 councils state they will accept correspondence (including e-mail) in Irish, and then have it translated if necessary. Eight of these councils will also respond in Irish, through the use of translation as needed. Only three councils report that they will accept correspondence in Ulster Scots, and all three report they will reply in that same language. Fourteen of the local councils report they translate written documents for public consumption into Irish. Only one of them reports doing this in house. The outside 
providers that are hired to do this translation work are local companies. The commitment to translate documents into Ulster Scots is much weaker. Local councils express a willingness to do it if the need should arise, but they also report much difficulty trying to find qualified translators to do the job. In fact, five of the local councils specifically reported they will not engage in any written translation for Ulster Scots.

Regarding interpreting, when people call into the council, staff members who can handle calls in Irish or Ulster Scots are often encouraged to do so. No council reports a policy of using interpreters to handle telephone calls. If the caller wishes to use Irish and no staff member can handle such a call, three councils offer the option of writing in while six also offer the option of leaving a voicemail in Irish. (Translation would then be employed to handle the request or inquiry.) For Ulster Scots, only three councils give the option of writing in and only one reports an Ulster Scots voicemail service. Should individuals want to use Irish in person or in meetings, interpreters for Irish will be provided by seven councils, with certain provisos such as advanced notice. Two councils report the use of interpreters for Ulster Scots for interacting with staff or for meetings.

The preceding paragraphs paint a picture where translation for Northern Ireland's autochthonous minority languages, when offered, is prioritized for Irish over Ulster Scots. This can be understood as a result of the influence of the ECRML in Northern Ireland. As ratified by the UK, it provides the more specific protections of Part III to Irish and offers only the more general statements of Part II to Ulster Scots. Part II is not very helpful 'as a blueprint for action' (Millar, 2006, p. 66). The devolved government in Northern Ireland has a policy to follow ECHR principles, as ratified, and this is reflected in the differential translation commitments of local governments for these two languages. Evidence of this can be seen in that more local councils report Codes of Courtesy for Irish than for Ulster Scots. Even so, it should be noted that each council's commitment to Irish varies, and the issue can at times become contemptuous as measures in favor of Irish are interpreted by some individuals as attacks on unionists and/or Protestants. 8 The delicate political balance between nationalists and unionists sought after in the Good Friday Agreement thus plays out in local councils, even in translation policy.

Conclusion: From policies on good relations, non-discrimination, human rights, and 


\section{language to translation policy}

By way of conclusion, this paper takes as its starting point the claim that there is no language policy without an attendant translation policy. It comes to this claim by extrapolating that a language policy in a multilingual society will result in management, practices, and beliefs about translation. Translation policy in Northern Ireland's public sector has been explored as an example of how these elements can play out. We have indicated that translation policy is not handled by a single organization or dictated from a single source. In Northern Ireland, policy direction comes from Westminster and also from devolved government bodies. But not only from there. When considering specific sectors-namely the judiciary, healthcare, and local governments - there are added layers of complexity resulting from the interaction of policy direction coming from Westminster, the devolved government and its institutions, and service providers in courts, HSC Trusts, and local government councils. Further, local non-profit organizations, such as STEP, help give shape to translation policy by being part of translation practices, and service providers respond not only to pressures from above but also to pressures that come from the people they serve and the organizations they interact with. Thus, specific translation policies are created through a complex and fluid interaction of politics, direction from above, demographics, and local needs and interests, which are often tied to historical, cultural, and economic specifics.

Admittedly, this study presents a snapshot. Translation policy is not static, and changes can come at any time from different sources. For example, the adoption of an Irish Language Act would affect at least some aspects of Irish-English translation policy. Nonetheless, the snapshot is helpful, among other reasons, because it reflects certain beliefs about translation. To understand these beliefs, we should remember that Northern Ireland's not-so-distant past is one of conflict that saw the region divided among cultural, religious, and political lines. Language became a dimension of that struggle. In order to help the region's communities deal peacefully with their differences, policy makers created a constitutional structure that has resulted in Irish and Ulster Scots being promoted to varying degrees. This structure links respect for those languages to the promotion of good relations between Northern Ireland's communities. Similarly, non-discrimination as a policy also became linked to the idea of establishing good relations, particularly in terms of the need to promote civil rights in order to grant equality for Catholics (Darby, 1995, 17-18). Translation has become one of several tools to further the ultimate aims of helping society overcome past inequalities and thus foster good relations now and in the future. This means that there is a belief, even if 
not always explicitly enunciated, that translation can help bring about a degree of inclusion that fosters good relations among communities and can eventually help build a more united society.

The policy of non-discrimination plays a central role in justifying translation services for immigrant communities. Of course, the issue is more complex than that for these particular communities because in the UK there are assimilationist pressures aimed at immigrants. One belief that the media has focused on is the idea that offering translation to those who do not speak English will discourage them from learning English (Tipton, 2012). However, in Northern Ireland the efforts to overcome segregation and conflict have led to seeing public recognition of ethnic minorities as a way to increasing participation in society and the life of the state, more so than in other places (McDermott, 2012, p. 193). Thus, inasmuch as translation is a tool for the recognition of Irish and Ulster Scots and a way to increase the participation of immigrants, it is a tool for fostering good relations. This is recognized in several documents analyzed for this study, including the above-mentioned Best Practice Guidelines on the Use of Translation.

In analyzing these beliefs regarding the aims served by translation, what emerges is a picture where translation serves many more purposes than supporting language policy. Thus, we can say that while translation policy is the result of language policy, it is also the result of other policies that interact with language policy in different ways and at different levels. Thus, in Northern Ireland translation policy is built on decisions that reflect language institutionalization and also on decisions that reflect the region's constitutional structure as well as legislative enactments that deal with rights such as the rights to a fair trial, to life, and to non-discrimination; translation policy comes about through the practice of devolved government bodies and also through the practice of local organizations; translation policy is built on the premise that in a post-conflict society translation can help promote languages that act as important symbols of cultural identity and also on the premise that communication through language barriers can help foster good relations among communities.

Consequently, translation policy is developed at many levels, by different actors, and in different ways. This translation policy in the public sector further interacts with other policies, such as educational or media policies, to create an organic web that impacts language choices by individuals and institutions. This is indeed a complex practice that deserves further study, including research on the specific ways 
these different levels and actors interact and just to what extent these translation policies do in fact improve good relations, non-discrimination, and human rights, all in light of everevolving language policies.

\section{Acknowledgments}

The author would like to thank Esmaeil Haddadian Moghaddam for his feedback during the drafting of this paper. This paper was drafted in the framework of TIME (Translator Research Training: An integrated and intersectoral model for Europe), a Marie Curie Initial Training Network (FP7-PEOPLE-2010-ITN) established with support from the European Commission.

\section{Notes}

1. In adopting this definition of translation policy, it is not our intention to say that language and translation are to be understood conceptually the same way. While translation policy is not synonymous with language policy, translation policy is not independent from language policy. Thus, approaches that are helpful for language policy conceptualization may also help conceptualize translation policy. Even so, translation policy can still be analyzed as policy in its own right, which is what is done in this study.

2. This may be slowly changing. For example, a community center in East Belfast is teaching the Irish language to Protestants, something that would have been very unlikely ten years ago (Schrank, 2013).

3. A Shared Future was an initiative of the Northern Ireland Office during the 2002-2007 direct rule. The devolved government is currently in the process of adopting another policy document that will be called Cohesion, Sharing and Integration. As of this writing, the new policy has not been adopted, mostly due to contention among the political parties (McDermott, 2012, pp. 193-194). A number of ideas in the yet-to-beadopted policy document "have seeped into the consciousness of government departments, cultural institutions, regional arts bodies and local city authorities" (McDermott, 2012, p. 194); however, because no final shape has yet been given to the policy and it remains to be seen how much translation will be a part of it, this paper considers only the impact that $A$ Shared Future has had on translation in Northern Ireland.

4. Now the Northern Ireland Courts and Tribunals Service, this agency is charged with running the courts of Northern Ireland.

5. This 'short guide' was produced in 2011 as an updated, slimmed-down version of 2003's Racial Equality in Health and Social Care: Good Practice Guide. The 2011 short guide does not replace, but rather compliment, the 2003 guide.

6. Many healthcare providers have come to rely on the NIHSSISS service. When it first started operating in 2005, it received 7,707 requests for medical interpreters, yet the requests increased gradually, and in 2009 it received over 40,000 requests (McDermott, 2011, p. 136-137).

7. The Northern Ireland Ambulance Service is not analyzed because, as the name indicates, it has a 
different remit than the other HSC Trusts.

8. An example of this is the controversy that broke out in the Dungannon and South Tyrone council when a receptionist answered the telephone in Irish. This was interpreted by some as a sign that the council was becoming hostile to Protestants ('Irish telephone call,' 2013).

\section{References}

Community Relations Unit (2005). A shared future: Policy and strategic framework for good relations in Northern Ireland. Belfast: Office of the First Minister \& Deputy First Minister. Retrieved from http://www.ofmdfmni.gov.uk/asharedfuturepolicy2005.pdf

Darby, J. (1995) Conflict in Northern Ireland: A background essay. In S. Dunn (Ed.), Facets of the conflict in Northern Ireland (p. 15-23). New York: St. Martin's Press.

Department for Communities and Local Government (2010). Third report submitted by the United Kingdom pursuant to Article 25, paragraph 2 of the Framework Convention for the Protection of National Minorities. Strasbourg: Council of Europe. Retrieved from http://www.coe.int/t/dghl/monitoring/minorities/3_FCNMdocs/PDF_3rd_SR_UK_en.pdf

Department of Health, Social Services and Public Safety (2008). Equality, Good Relations and Human Rights Strategy and Action Plan. Retrieved from http://www.dhsspsni.gov.uk/strategyandactionplan.pdf

Dickson, B. (2003). Language rights and human rights: The Northern Ireland experience. In D. Ó Riagáin (Ed.), Language and Law in Northern Ireland (pp. 17-23). Belfast: Queen's University Belfast.

Dunbar, R. (2003). The ratification by the United Kingdom of the European Charter for Regional or Minority Languages. Mercator Working Papers. Retrieved from www.ciemen.org/mercator/pdf/WP10-def-ang.pdf

Dunbar, R. (2004). Language legislation and language rights in the United Kingdom. In European Centre for Minority Issues \& The European Academy Bozen/Bolzano (Eds.), European Yearbook of Minority Issues, Volume 2, 2002/3 (pp. 95-126). Leiden: Martinus 
Nijhoff.

Dunbar, R. (2007). Diversity in addressing diversity: Canadian and British legislative approaches to linguistic minorities, and their international legal context. In C. Williams (Ed.), Language and Governance (pp. 104-158). Cardiff: University of Wales Press.

Equality Commission for Northern Ireland (2011). Racial equality in health and social care: A short guide to good practice in service provision. Belfast: Department of Health, Social Services and Public Safety. Retrieved from http://www.dhsspsni.gov.uk/race_equality_guide_march_2011.pdf

Gilbert, A. (2003). Ulster-Scots in education in Northern Ireland: The history of the language. In D. Ó Riagáin (Ed.), Language and Law in Northern Ireland (pp. 78-87). Belfast: Queen's University Belfast.

Holder, D. (2003). In Other Words? Mapping Minority Ethnic Languages in NI. Belfast: Multi-Cultural Resource Centre NI. Retrieved from http://www.mcrcni.org/PDFs/InOtherWords.pdf

Holder, D. (2010). Why the use of Irish in the courts is important. The Use of Irish in the Courts in the North of Ireland: Report of the Event, 13-15.

Houses of the Oireachtas (2010). Other Questions - Irish Language. Retrieved from http://debates.oireachtas.ie/dail/2010/05/11/00010.asp

Interdepartmental Charter Implementation Group (2005). Guidance on meeting UK government commitments in respect of Irish and Ulster Scots. Retrieved from http://www.dcalni.gov.uk/european_charter_guidance.doc

Irish telephone call incident 'resolved'. (2013, January 17). Mid-Ulster Mail. Retrieved from http://www.midulstermail.co.uk/news/local/irish-telephone-call-incident-resolved-1-4695546

Kirk, J. M., \& Ó Baoill, D. P. (2001). Introduction: Linguistic politics in the gaeltacht and the schotstacht. In J. M. Kirk \& D. P. Ó Baoill (Eds.), Linguistic politics: Language policies for 
Northern Ireland, the Republic of Ireland, and Scotland (pp. 1-21). Belfast: Cló Ollscoil na Banríona.

Kymlicka, W. (2007). Language policies, national identities, and liberal-democratic norms. In C. Williams (Ed.), Language and Governance (pp. 505-515). Cardiff: University of Wales Press.

Laird, J. D. (20010). Language policy and the Ulster-Scots Agency. In J. M. Kirk \& D. P. Ó Baoill (Eds.), Linguistic politics: Language policies for Northern Ireland, the Republic of Ireland, and Scotland (pp. 37-41). Belfast: Cló Ollscoil na Banríona.

Larkin, J. F. (2010). The Irish language in the courts of Northern Ireland. The Use of Irish in the Courts in the North of Ireland: Report of the Event, 13-15.

McEvoy, J. (2011). Managing culture in post-conflict societies. Contemporary Social Science, $6: 1,55-71$.

McDermott, P. (2008). Towards linguistic diversity? Community languages in Northern Ireland. Shared Space, 5, 5-20.

McDermott, P. (2011). Migrant languages in the public space: A case study from Northern Ireland. Berlin, Münster, Vienna, Zurich, London: Lit Verlag.

McDermott, P. (2012). Cohesion, sharing and integration? Migrant languages and cultural spaces in Northern Ireland's urban environment. Current Issues in Language Planning, 13, $187-205$.

Meylaerts, R. (2011a). Translation policy. In Y. Gambier \& L. Van Doorslaer (Eds.), Handbook of Translation Studies: Volume 2 (pp. 163-168). Amsterdam, New York: Benjamins.

Meylaerts, R. (2011b). Translational justice in a multilingual world. Meta, 56, 743-757.

Millar, R. M. (2006). 'Burying alive': Unfocussed governmental language policy and Scots. 
Language Policy, 5, 63-86.

Nic Craith, M. (2001). Cultural diversity in Northern Ireland and the Good Friday Agreement. Working Papers in British-Irish Studies, 7, 1-19. Retrieved from http://www.ucd.ie/ibis/filestore/wp2001/07_nicra.pdf

Northern Ireland Assembly (2008). Official Report (Hansard). Retrieved from http://www.niassembly.gov.uk/Assembly-Business/Official-Report/Committee-Minutes-ofEvidence/Session-2007-2008/February-2008/Foras-na-Gaeilge/

Northern Ireland Assembly (2009). Official Report (Hansard). Retrieved from http://archive.niassembly.gov.uk/qanda/2007mandate/writtenans/2008/pdf/090109.pdf

Northern Ireland Courts and Tribunals Service (2012a). Interpreter and translation service. Retrieved from http://www.courtsni.gov.uk/en-GB/Services/InterpreterationServices/Pages/default.aspx

Northern Ireland Courts and Tribunals Service (2012b). Interpreter and translation services quarterly bulletin. Retrieved from http://www.courtsni.gov.uk/enGB/Publications/Targets_and_Performance/Documents/tp-q212interpreters/p_tp_QuartInterpretReportQ3-12.pdf

Northern Ireland Statistics and Research Agency (2012). Census 2011: Key Statistics for Northern Ireland. Retrieved from http://www.nisra.gov.uk/Census/key_report_2011.pdf

Ó Flannagáin, M. (2010). The 1737 Act and the Challenge of Equality. The Use of Irish in the Courts in the North of Ireland: Report of the Event, 10-11.

O’Rourke, B. \& Castillo, P. (2009). ‘Top down' or ‘bottom-up'?: Language policies in public service interpreting in the Republic of Ireland, Scotland, and Spain. In R. de Pedro Ricoy, I. A. Perez, \& C. W. L. Wilson (Eds.), Interpreting and translating in public service settings: Policy, practice, pedagogy (pp. 33-51). Manchester and Kinderhook: St. Jerome.

Racial Equality Forum (2008). Best practice guidelines on the use of interpreters. Belfast: 
Office of the First Minister and Deputy First Minister. Retrieved from http://www.belfastcity.gov.uk/migrants/docs/interpretersguidelines.doc

Racial Equality Forum (2009). Best practice guidelines on the use of translation. Belfast: Office of the First Minister and Deputy First Minister. Retrieved from http://www.belfastcity.gov.uk/migrants/docs/translatorsguidelines.doc

Rooney, E. (2001). Language policy implementation: A DCAL civil servant's perspective. In J. M. Kirk \& D. P. Ó Baoill (Eds.), Linguistic politics: Language policies for Northern Ireland, the Republic of Ireland, and Scotland (pp. 55-60). Belfast: Cló Ollscoil na Banríona.

Schrank, A. (2013). A new Protestant beginning for the Irish language in Belfast. Retrieved from http://www.theworld.org/2013/04/a-new-protestant-beginning-for-the-irish-language-inbelfast/

Smyth, A. \& Montgomery, M. (2005). The Ulster-Scots Academy. In J. M. Kirk \& D. P. Ó Baoill (Eds.), Legislation, literature and sociolinguistics: Northern Ireland, the Republic of Ireland, and Scotland (p. 60-64). Belfast: Cló Ollscoil na Banríona.

Spolsky, B. (2012). What is language policy?. In B. Spolsky (Ed.), The Cambridge Handbook of Language Policy (pp. 3-15). Cambridge: Cambridge University Press.

Tipton, R. (2012). Public service interpreting and the politics of entitlement for new entrants to the United Kingdom. Journal of Language \& Politics 11, 185206.

Walsh, J. (2012). Language policy and language governance: A case-study of Irish language legislation. Language Policy 11, 323-341.

This is an Author's Accepted Manuscript of an article published in Current Issues in Language Planning 14(3), (C) Taylor \& Francis, available online at:

http://www.tandfonline.com/10. 1080/14664208.2013.827036 